\title{
Stop making it weird: Why I'm not clapping
}

\author{
Cassandra J. Davis ${ }^{\mathrm{a}, *}$ and Jolene M. Thibedeau Boyd ${ }^{\mathrm{b}}$ \\ ${ }^{\mathrm{a}}$ Association for People Supporting EmploymentFirst, Rockville, MD, USA \\ ${ }^{\mathrm{b}}$ Community Involvement Programs, Minneapolis, MN, USA
}

Revised/Accepted November 2016

\begin{abstract}
.
BACKGROUND: People with disabilities today have greater opportunities for inclusion and full community engagement than ever before. There is an increasing importance placed on supporting higher expectations: More people have jobs where they work alongside co-workers without a focus on disability. Innovative leaders recognize that all employees do better when they have support tailored to their unique skills and work styles. Yet many disability professionals continue to hold unconscious beliefs that influence their actions, well-intentioned as they may be, and ultimately create situations that are unnatural and bizarre-in a word, "weird".

OBJECTIVE: It is time for a dialogue about how this has led to the perpetuation of unwanted "special treatment," low expectations, and institutionalized segregation of people with disabilities.

CONCLUSION: The authors outline ways people can "stop making it weird" and share the campaign of the same name.
\end{abstract}

Keywords: Unconscious beliefs, low expectations, special treatment, inspiration porn, disability is not exceptional, inclusion, community engagement, \#stopmakingitweird

\section{Introduction}

Have you ever walked into an empty restroom full of urinals only to have another person walk in and stand right beside you? Have you ever been in an empty gym full of treadmills where one person arrived and took the treadmill right next to you? Perhaps it was a pool with several empty lanes, a bus full of empty seats, or a waiting room full of chairs. No matter the situation or environment, this type of behavior makes most people feel uncomfortable, perhaps even weird. "Why did they have to choose that one?" we ask ourselves. While some people may go out of their way to be intentionally provocative, what about those who act in ways that make things weird for people with disabilities, and in ways that are so insidious that they go largely unnoticed by most,

*Address for correspondence: Cassandra J. Davis, 414 Hungerford Drive, Suite 224, Rockville, MD 20850, USA. Tel.: +1 612 385 5122; E-mail: cassy@ apse.org. including disability professionals? This question can be further complicated by the fact that those who act in such ways seem to do so with only the best of intentions.

In the field of disability services, there is a great deal of disagreement when it comes to service models and expectations for people who have disabilities: segregated housing vs. community living, segregated work settings vs. community employment (National Disability Rights Network, 2011), special education vs. inclusive classrooms (Csillag, 2014), Special Olympics or adaptive recreation vs. typical sports activities done with adequate support (Mayer \& Anderson, 2014). Many practitioners in this field consider themselves progressive, stating a belief in people with disabilities living typical lives just like anyone else. However, many of us have developed unconscious habits that unintentionally and subversively belittle those whom we claim to want to help live typical lives. 


\section{Genesis of stop making it weird}

Imagine that during a panel presentation at a conference, each presenter introduces the next speaker with little fanfare. Each presenter stands to share his or her portion of the presentation and then returns to his or her seat as the audience silently anticipates the next speaker. Then a presenter with a visible disability finishes her portion and prepares to hand-off to the next person. The audience claps wildly, apparently for no reason other than the fact that she has a disability; unknowingly, this crowd has just made it weird. They've excessively celebrated a woman for doing nothing more than the woman to her left or the man to her right. Next, imagine a fourth-grade boy with a learning disability writing his name on his quiz. His teacher walks over to offer an encouraging "high-five", although she doesn't do the same for any of his peers. This type of encouragement is just another reminder to the boy and his classmates that he is somehow different. Although we may recognize the importance of full inclusion and raising expectations for people with disabilities, even well-intentioned behaviors can create situations that are weird.

Stop Making It Weird (\#stopmakingitweird) is a campaign to combat our own weirdness (in attitudes, actions, or beliefs) toward people with disabilities. It is the idea that often through our own good faith efforts we inadvertently cause unintended harm to those with disabilities by virtue of our own weirdness. These beliefs may manifest themselves as excessive celebration over a person completing what would ordinarily be considered a mundane or routine task. That is, it is celebrated because it has been done by someone with a disability, simply because they have a disability. There are many different ways to stop making it weird by building a culture that treats people as people, regardless of disability status (even at the risk of our own discomfort), by exploring our own attitudes and behaviors, by sharing personal experiences of people being treated differently based on perceived disabilities, and by utilizing an online forum to reach colleagues, friends, and family via electronic or social media.

In April of 2014, Australian comedian, journalist, and disability rights activist, Stella Young, took the TED (Technology, Entertainment and Design) stage in Sydney, Australia. She proceeded to share a nineminute talk that has now been viewed more than 2.2 million times; it was aptly titled, I' $m$ not your inspiration, thank you very much. In her talk, Stella stated:
I am here to tell you that we have been lied to about disability. We've been sold the lie that disability is a Bad Thing... and to live with a disability makes you exceptional. It's not a bad thing, and it doesn't make you exceptional. And in the past few years we've been able to propagate this lie even further with social media... [with] what we call inspiration porn....[T]hey objectify one group of people for the benefit of another group of people. So in this case, we're objectifying disabled people for the benefit of nondisabled people. The purpose of these images is to inspire you, to motivate you, so that we can look at them and think, "Well, however bad my life is, it could be worse. I could be that person." But what if you are that person? (Young, 2014).

Stella presented a direct challenge to those who share these types of stories and images as inspirations to be celebrated via social media. We all know them. Perhaps even some of us have shared them.

Blog writer, Crippled Scholar, agrees:

The stories that impact disabled people's lives should be told and they should never be diminished to the story that poses a balm to all the other bad news that surrounds it. Doing that is both dehumanizing and perpetuates harmful stereotypes about disabled people which does not lead to warm and fuzzy endings for the subject of your feel good moment (2015, para. 6-7).

She goes on to provide guidelines for viewing this type of media and making the distinction between newsworthiness and inspiration porn:

A good way to gauge whether a story about disability is news worthy is to ask these two questions.

1. If the subject of this story was replaced by a nondisabled person, would this still be news? If the answer is no, then you may want to reconsider it.

2. Who is the target audience, is it everyone (this includes disabled people) or is it meant to appeal predominantly to nondisabled people? If the latter you should definitely think twice before running with it. If you are unsure, you should consult with disabled people to see how they feel about the story (the plurality of people is really important here) (Crippled Scholar, 2015, para. 8). 
These guidelines offer us all a context from which to consider whether or not the stories we choose to tell are truly opportunities for celebration or actually make things weird by implying that simply because a person with a disability did something typical, there is reason for celebration.

\section{Is this weird?}

On January 26, 2016 The Sun Chronical published a story titled, "Norton High School wrestler no longer undefeated, but still a winner". The story is about two high school boys, one with Down syndrome and one without disability. The boy without disability was the undefeated captain of the wrestling team, a student whom some may consider to be a hero of sorts. Rick Foster, a staff writer for The Sun Chronicle wrote,

Howland, a 21-year-old transition student with Down syndrome, pinned one of the state's top Division 3 high school wrestlers to earn a victory in the triangular meet... Norton coach Pat Coleman said he was pleased the NHS senior put aside natural competitiveness to enable his opponent to claim a thrilling victory (2016, para. 2).

As a result, Devon Schuko, the student without disability, becomes the hero and focus of the story. The article makes several references to the fact that he's an honor student, member of the Spanish National Honor Society, and is a "real squared-away kid" (Foster, 2016, para. 5) per his coach. Schuko stated of the experience, "We just wanted to make his day" (Foster, 2016, para. 7). Throughout the article, Andy Howland, the wrestler with Down syndrome falls so far into the background he serves no purpose to the story other than being the object for which the other boy should be celebrated.

This is not the only story of its kind. In fact, there are dozens of these stories circulating on various social media outlets on any given day (see Young, 2014). Stories of people with disabilities who open businesses together and only employ other people with disabilities, stories of other young high school heroes who graciously offer to take a girl with Down syndrome to prom, apartment complexes and dance clubs built exclusively for those with disabilities. These articles make us wonder, in exactly which direction are we moving? Are we truly moving toward a more inclusive society? How are we able to do this if we are continually creating more ways to segregate those who experience disabilities? How can society be properly educated on the social model of disability when their only experience with disability is through articles such as the one published by The Sun Chronicle?

\section{Faltrusim}

In researching this topic, the authors searched for a word to describe this phenomenon, a simple way to describe these practices: Sharing stories about people with disabilities doing mundane things or participating in typical activities, only to be made into spectacles, objectified for the purpose of making the nondisabled population feel good. In 2016, a term to describe this was coined by Molly Franks of Bowie, Maryland, an employment professional providing supports to people with disabilities:

Faltruism: /'faltroo, izom/ (n). The belief in or practice of selfless concern for the well-being of others while consciously or sub-consciously doing so for the benefit of oneself. (personal communication, 2016).

According to the website Helpguide.org (n.d.), helping others makes us healthier and happier; some might even suggest that it is human nature to want to help. But how do we decide whom we chose to help? Often, it is those whom we view as less fortunate than we are, people for whom we feel sorry because they have been dealt what we perceive to be a bad hand in life. But what if our perceptions have led us to mistaken conclusions, based on our limited lived experiences? What if the person whom we perceive to have been dealt a bad hand has just been dealt a hand that looks different than ours? What does that make us as the helpers, and are we helping that person at all?

Whether we realize it or not, we often help people for some type of personal benefit, whether consciously to gain praise or notoriety or subconsciously because it just makes us feel good (Helpguide.org, n.d.). While these ideas alone may not seem all that terrible, they may be compounded by the fact that the help that is being offered may, we assume unintentionally, dehumanize the person who is being helped. When someone forfeits a win to a person with a disability, perhaps to help that person feel successful, the whole experience for that person has been cheapened. The message conveyed relies on the faulty assumption that the person with disability cannot possibly win legitimately, of their own volition, because they 
are one of those unfortunate people who have been dealt a bad hand. Meanwhile the "helper" becomes the hero in the situation, gaining praise, recognition and possibly even press for their good deed.

Perhaps ironically, one of the plotlines of the popular American comedy-drama web television series, Orange Is the New Black, presents us with a refreshing contrast to the story published by The Sun Chronicle, while underscoring how behaviors such as this can make things weird, unintentional though it may be. The scene in episode 11 of season three takes place in a high school gymnasium; the wrestling coach is speaking to his team, recognizing his top wrestler (who is young Joey Caputo, one of the show's characters) for being a hero because he's agreed to wrestle a student from a competing school who has a disability. Joey announces to the team that he's going to let the other student really feel like he's winning. Joey revels in the praise showered on him by his coach, and then by his girlfriend, who tells him he's amazing. When the two wrestlers get in the ring, Joey tells the other student to go easy on him, to which the other student replies, "No way." Before Joey knows what has happened, the student with a disability throws Joey to the ground and pins him, leaving Joey with a wrestling career-ending shoulder injury (Kohan, Heder, \& Abraham, 2014). This scene has so many parallels to The Sun Chronicle story that it almost seems to be a parody of it. Even the episode's title, We Can Be Heroes, echoes the sentiment of the newspaper article. In the web television episode, the young Joey Caputo, states, "I'm gonna [sic] let him feel like he's really doing it," while Devon Schuko, the star wrestler in The Sun Chronicle article states, "We just wanted to make his day." The similarities are hard to deny and both are classic examples of faltruism.

As Crippled Scholar put it,

I am not suggesting that nondisabled people shouldn't help disabled people. They absolutely should but they should not do so in search of accolades. They should also avoid those accolades unless they come from the person they are helping. Otherwise it is just nondisabled people patting other nondisabled people on the back for helping disabled people and then dehumanizing them by publicizing their life without their input. (2015, para. 15)

\section{What is not making it weird?}

Identifying something that is weird is only the first step, however. How do we actually stop making it weird? An example of this was shared with one of the authors recently: At a conference, one of the speakers, a military veteran who lost both of his legs in combat, shared a personal experience. When he returned home from combat, the veteran, newly disabled, tried to resume the life he had once known; however, it was evident that the people with whom he had once been close now seemed unsure of how to interact with him. When he later went on a hunting trip with a group of his friends and acquaintances, he was surprised by how they treated him. The other hunters were joking with him, teasing him, even making fun of him, and nothing was off-limits, not even the topic of his lost limbs. He told the audience that he had thanked the hunters who had made fun of him. He said they were the first people since his return who had treated him just like the normal guy he was. This is not making it weird.

\section{Join the movement}

The time is now to join the \#stopmakingitweird movement. More people with disabilities than ever before are living typical lives, living in regular homes and holding regular jobs. We cannot continue to make progress without questioning the actions, words, and thoughts that we have about people with disabilities, as well as doing so with those around us. Take the pledge to \#stopmakingitweird by going to www.stopmakingitweird.com, and join us in sharing and continuing the conversation on Facebook at www.facebook.com/stopmakingitweird

Perhaps the late Stella Young said it best in the closing remark of her 2014 TED Talk: "Disability doesn't make you exceptional, but questioning what you think you know about it does."

\section{Conflict of interest}

The authors have no conflict of interest to report.

\section{References}

Crippled Scholar (2015). A media guide for nondisabled people talking about innovations for disabled people [Web $\log$ comment]. Retrieved from https://crippledscholar. wordpress.com/2015/08/06/a-media-guide-for-nondisabledpeople-talking-about-innovations-for-disabled-people/ 
Crippled Scholar (2015). Disabled people don't exist to make you look good [Web log comment]. Retrieved from https://crippledscholar.wordpress.com/2015/05/20/

Csillag, J. (2014). Inclusion vs. special education classrooms: What are the differences? Retrieved from https://www.noodle. com/articles/inclusion-vs-special-education-classroomswhat-are-the-differences

Foster, R. (2016). Norton High School wrestler no longer undefeated, but still a winner [Electronic version]. The Sun Chronicle. Retrieved from http://www.thesunchronicle.com/ news/local_news/norton-high-school-wrestler-no-longer-unde feated-but-still-a/article_2ce2861b-f56e-512c-b4c0-15af7bf5 7a33.html

Helpguide.org (n.d.). Volunteering and its surprising benefits. Retrieved from http://www.helpguide.org/articles/workcareer/volunteering-and-its-surprising-benefits.htm
Kohan, J., Heder, S., \& Abraham, P. (2015). We can be heroes [Online television series episode]. In J. Kohan (Producer), Orange Is the New Black. Rockland County, NY: Lionsgate Television.

Mayer, W. E., \& Anderson, L. S. (2014). Perceptions of people with disabilities and their families about segregated and inclusive recreation involvement [Abstract]. Therapeutic Recreation Journal, 48(2), 150.

National Disability Rights Network (2011). Segregated and Exploited: The Failure of the Disability Service System to Provide Quality Work. Washington DC: National Disability Rights Network.

Young, S. (2014). I'm not your inspiration, thank you very much [Video file]. Retrieved from https://www.ted.com/talks/ stella_young_i_m_not_your_inspiration_thank_you_very_much 